\section{International Scientific Journal Theoretical \& Applied Science}

p-ISSN: 2308-4944 (print) e-ISSN: 2409-0085 (online)

Year: $2018 \quad$ Issue: $03 \quad$ Volume: 59

Published: $14.03 .2018 \quad \underline{\text { http://T-Science.org }}$
Reza Fathollahzadeh hachesou

Ph.D. student in Educatiional administration Department of elementary, chabahar Branch

Islamic Azad University, chabahar, Iran

Salim Balouch

MA in Educational administration, Education, nikshhr, sistan\&balouchestan, Iran

SECTION 24. Sociological research.

\title{
WHAT IS THE EFFECT OF WORKPLACE SPIRITUALITY ON ORGANIZATIONAL CITIZENSHIP BEHAVIOR OF THE TEACHERS?
}

\begin{abstract}
The main purpose of this research is to study the relation of workplace spirituality and its components with middle school teachers' organizational citizenship behavior (OCB) in school year of 2017-18. This is an applied study as well as descriptive-correlational type in terms of the nature of the subject and objectives of the study. The statistical population consists of all middle school teachers of Nikshahr County that are 164 persons. To implement the study, 113 people were selected of the statistical population in a stratified random sampling. Millman's standard questionnaire with the reliability of 0.91, Organ and Kanoski's questionnaire of organizational citizenship behavior with the reliability of 0.86 , have been used to measure workplace spirituality and citizenship behavior respectively. The information obtained was analyzed at the level of inferential statistics (correlation coefficient and multivariable regression tests). The results indicated that there is a significant correlation between workplace spirituality and its components and employees' organizational citizenship behavior. Among those components, alignment with organization's values and meaningful work showed multiple correlations with employees' organizational citizenship behavior. Therefor, alignment with organization's values and meaningful work explain the increase in organizational citizenship behaviors among teachers.

Key words: Teachers, OCB, Organizational spirituality

Language: English

Citation: Fathollahzadeh hachesou R, Balouch S (2018) WHAT IS THE EFFECT OF WORKPLACE SPIRITUALITY ON ORGANIZATIONAL CITIZENSHIP BEHAVIOR OF THE TEACHERS? ISJ Theoretical \& Applied Science, 03 (59): 81-85.

Soi: http://s-o-i.org/1.1/TAS-03-59-12 Doi: crossef https://dx.doi.org/10.15863/TAS.2018.03.59.12
\end{abstract}

\section{Introduction}

Organizational activities are under all kinds of pressures from inside and outside; and in today's world of change and transformation those organizations will be successful who can adapt themselves to the existing situations [12]. Organizations whose employees have high spirituality can adapt themselves to the environment [5]. Based on this fact, workplace spirituality is one of the concepts discussed when it comes to human resource growth. Workplace spirituality refers to identification and understanding of an individual's aspect of vocational life that is intrinsic and cultivatable; and it is brought up and cultivated through carrying out works in one's social life that bare meaning [3]. In this study we have used conceptualization of workplace spirituality by Milliman et al. (2003) who discussed three of the seven aspects proposed by [3] to evaluate workplace spirituality. These three aspects which correspond to three levels of personal, communal, and organizational are: meaningful work in personal level, sense of community in communal level, and alignment with organization's values in organizational level. Meaningful work: is built on the proposition that each individual has an internal motivation, tendency and attitude to carry out activities that give meaning to his life and the lives of other people [3]. Sense of community: includes the feeling of being connected to others and having common purposes with them [7]. Alignment with organization's values: means that employees believe that managers and co-workers in their organization have respectable values, moral conscience and value employees' and society's welfare [3]. The concept of organizational citizenship behavior (OCB) was first introduced by Organ \& Bateman (1983) and is defined as employees' behavior that is beyond organizational rules; and although it is not identified and applauded by the organization, it has a great effect on organization's performance [6]. Organizational citizenship behavior a new model for 
employees' behavior is used as the modern approach to human resources in many organizations [9]. Organizational citizenship behaviors include cooperation with coworkers, self-increase, and creating a sense of teamwork. In this sense, employees see the benefit of the organization as a value and prevent actions and decisions that would reduce organization's resources [15]. An example of organizational citizenship behavior among teachers is voluntary assistance to students, coworkers and other people even after work hours and in personal time. Such teachers focus on proposing innovative suggestions and professional activities and use their capacity for the benefit of school and expect no rewards in return [8]. Therefor, in this research we try to identify and reinforce workplace spirituality to increase teachers' organizational citizenship behavior; and through that, increase teachers' efficiency.

\section{Materials and methods}

This is an applied research, and due to the nature of the subject and objectives the study research is descriptive correlational. The statistical population consists of all middle school teachers (male and female) of Nikshahr County in 2017-18 school years that are 164 persons. The sample size was selected 113 people using Morgan table and in a stratified random sampling method. A standard questionnaire by Millman et al. (2003), Organ and Kanoski's (1996) have been used to measure workplace spirituality and citizenship behavior respectively. To assess the validity of workplace spirituality questionnaire and organizational citizenship behavior of the questionnaires were provided to university professors to comment on the appropriateness of the items and components with the scales. The employees' workplace spirituality questionnaire consists of 14 items and organizational citizenship behavior questionnaire consists of 15 items in which Likert 5-point scale has been used. The questionnaires' reliability for organizational spirituality and organizational citizenship behavior was calculated, using Cronbach's alpha, as 0.91 and 0.86 respectively. And data was analyzed using Pearson correlation coefficient and multivariable regression through spss software (version 21).

\section{Results}

Of the total number of respondents (113 people), 60persons $(53.1 \%)$ are male and 53 persons $(49.6 \%)$ are female, also 113 people $(11.5 \%)$ have associate's degree, 80 people $(70.8 \%)$ have bachelor's degree, and 20 people $(17.7 \%)$ have Master's degree.

Table1

\section{Descriptive statistics indices for workplace spirituality and organizational citizenship behavior}

\begin{tabular}{cccc}
\hline Variable & Mean & SD & N \\
\hline Workplace spirituality & 49.92 & 10.61 & 113 \\
Organizational citizenship behavior & 49.23 & 7.68 & 113 \\
\hline
\end{tabular}

Mean and standard deviation for components of workplace spirituality

\begin{tabular}{cccc}
\hline Workplace spirituality components & Mean & SD & N \\
\hline Meaningful work & 18.91 & 4.01 & 113 \\
Sense of community & 18.14 & 4.05 & 113 \\
\hline Alignment with organization's values & 12.87 & 4.12 & 113 \\
\hline
\end{tabular}

First hypothesis: there is a significant correlation between workplace spirituality and its components and teachers' organizational citizenship behavior. 


\section{Impact Factor:}

\begin{tabular}{lr|lr|} 
ISRA $($ India $)$ & $=\mathbf{1 . 3 4 4}$ & SIS $($ USA) & $=\mathbf{0 . 9 1 2}$ \\
ISI $($ Dubai, UAE) & $=\mathbf{0 . 8 2 9}$ & PИНЦ $($ Russia $)=\mathbf{0 . 2 0 7}$ \\
GIF $($ Australia) & $=\mathbf{0 . 5 6 4}$ & ESJI $($ KZ $)$ & $=\mathbf{4 . 1 0 2}$ \\
JIF & $=\mathbf{1 . 5 0 0}$ & SJIF $($ Morocco $)=\mathbf{2 . 0 3 1}$
\end{tabular}

Assessment of correlation between workplace spirituality and its components and organizational citizenship behavior

\begin{tabular}{|c|c|c|c|c|c|c|c|}
\hline Row & $\begin{array}{c}\text { Correlation } \\
\text { table }\end{array}$ & OCB & $\begin{array}{l}\text { Meaningful } \\
\text { work }\end{array}$ & $\begin{array}{c}\text { Sense of } \\
\text { community }\end{array}$ & $\begin{array}{c}\text { Alignment } \\
\text { with } \\
\text { organization's } \\
\text { values }\end{array}$ & $\begin{array}{l}\text { Workplace } \\
\text { spirituality }\end{array}$ & Sig \\
\hline 1 & Meaningful work & 0.583 & 1 & & & & 0.000 \\
\hline 2 & $\begin{array}{l}\text { Sense of } \\
\text { community }\end{array}$ & 0.567 & 0.599 & 1 & & & 0.000 \\
\hline 3 & $\begin{array}{c}\text { Alignment with } \\
\text { organization's } \\
\text { values }\end{array}$ & 0.643 & 0.639 & 0.673 & 1 & & 0.000 \\
\hline 4 & $\begin{array}{l}\text { Workplace } \\
\text { spirituality }\end{array}$ & 0.687 & - & - & - & 1 & 0.000 \\
\hline
\end{tabular}

As demonstrated in table 3, level of significance for workplace spirituality and its components with organizational citizenship behavior is smaller than 0.05 , that is, less than 0.05 error; therefor with $95 \%$ confidence it can be concluded that there is a significant correlation between workplace spirituality and its components and organizational citizenship behavior among teachers. Also the obtained correlation coefficient for all the components is positive. This shows that the increase in workplace spirituality and its components will lead to increase in organizational citizenship behavior of teachers. Therefor the main hypothesis is accepted and the null hypothesis is rejected.

Second hypothesis: a combination of components of workplace spirituality explains the increase in organizational citizenship behavior of teachers.

Table4

Summary of the results of stepwise regression analysis for prediction of organizational citizenship behavior

$\begin{array}{ccccc}\text { Statistical indices/ } & \text { Coefficient of } & \mathbf{R}^{2} & \text { Adjusted } \\ \text { the components in the analysi } & \begin{array}{c}\text { multiple } \\ \text { correlation }\end{array} & \begin{array}{c}\text { Standard } \\ \text { correlation } \\ \text { coefficient }\end{array} & \begin{array}{c}\text { of the } \\ \text { estimate }\end{array}\end{array}$

\begin{tabular}{ccccc}
\hline $\begin{array}{c}\text { Alignment with } \\
\text { organization's values } \\
\text { Meaningful work }\end{array}$ & 0.643 & 0.414 & 0.409 & 5.90 \\
\hline
\end{tabular}

As indicated in table 4 , in stepwise regression analysis, aspect of alignment with organization's values has multiple correlations with organizational citizenship behavior. Based on importance, the priority of predictive variables in stepwise regression analysis is in first step with alignment with organizational values with correlation coefficient of 0.643. In the second step, with addition of the aspect of meaningful work, correlation coefficient rises to 0.681 . The added value to correlation coefficient for aspect of meaningful work is 0.03 . All in all, these two components can explain 0.464 changes in variance of organizational citizenship behavior, 0.414 of which is related to the component alignment with organization's values; and 0.05 is related to the component of meaningful work.

Table5

Analysis of variance for regression significance

\begin{tabular}{cccccc}
\hline Model & $\begin{array}{c}\text { Sum of } \\
\text { squares }\end{array}$ & DF & $\begin{array}{c}\text { Mean of } \\
\text { square }\end{array}$ & F & Sig. \\
\hline Regression & 3067.45 & 2 & 1533.72 & 47.57 & 0.000 \\
Residual & 3546.56 & 110 & 32.24 & & \\
Total & 6614.08 & 112 & - & & \\
\hline
\end{tabular}


According to table 5, the obtained F (47.57) which is significance with less than 0.01error, indicates that independent variable has a high predictive power and can well explain the rate of change and dependent variable's variance. In other words, regression model for this study is a good model and with its help we can explain changes in the dependent variable i.e. organizational citizenship behavior based on components of alignment with organization's values and meaningful work.

Standardized/unstandardized regression coefficients for prediction of OCB

Table6

\begin{tabular}{lllll}
\hline $\begin{array}{l}\text { Statistical } \\
\text { indices }\end{array}$ & Non-standard coefficients & $\begin{array}{l}\text { Beta } \\
\text { standard } \\
\text { coefficients }\end{array}$ & T & Sig \\
\hline
\end{tabular}

\begin{tabular}{|c|c|c|c|c|c|}
\hline Components & Beta & Stand & & & \\
\hline Constant & 27.73 & 2.58 & - & 10.73 & 0.000 \\
\hline $\begin{array}{l}\text { Alignment with } \\
\text { organization's } \\
\text { values }\end{array}$ & 0.85 & 0.169 & 0.458 & 5.04 & 0.000 \\
\hline $\begin{array}{l}\text { Meaningful } \\
\text { work }\end{array}$ & 0.55 & 0.174 & 0.290 & 3.19 & 0.002 \\
\hline
\end{tabular}

As demonstrated in table 6 , in the last (the second) step of stepwise regression analysis, the two components of alignment with organization's values and meaningful work were entered into the regression equation. In a respective manner as indicated in table 6, alignment with organization's value with Beta coefficient of $0.85(\mathrm{P}>0.000)$, and meaningful work with Beta coefficient of 0.55 $(\mathrm{P}>0.000)$ have a positive and significant relation. These results indicate that the increase in alignment with organization's value and meaningful work predicts the increase in organizational citizenship behavior of the teachers.

\section{Conclusion and discussion}

After the analysis if the data it was clear that there is a significant and positive relation between workplace spirituality and its aspect and organizational citizenship of the teachers. Aspects of alignment with organization's value and meaningful work can predict organizational citizenship behavior of the teachers. Results obtained in this research correspond to the results concluded in the studies of $[1,13,16,7,14,2,11,4,10,17]$. There are many instances that show great changes are happening in the organizations on the accounts of what is called spiritual movement. Organizations which were long viewed as intellectual systems are now turning their attention towards creating an environment of spirituality: aspects which are less related to rules and regulations and are more oriented with purposefulness and feeling of solidarity. Workplace spirituality helps employees focus more on important things in life: God, family, other people and the material world. This fundamental spirituality enables employees to have a better view of God and other people in their world.[17]. showed that spiritual employees have more meaningful and purposeful works and experiences, and this makes them more appreciative and helps them demonstrate more citizenship behaviors. It is necessary to mention that organizational spirituality is formed through contact with other people, and this issue make the employees more sensitive to other peoples' need and consequently brings out more organizational citizenship behaviors. Tepper also concluded that spiritual employees are more adapted to challenges that require faith, stability, and forgiveness; therefor positive relational and familial behaviors is more common among them [17].

Since our results indicated a positive and significant relation of workplace spirituality and its components with organizational citizenship behavior, the following suggestions are put forward for better efficiency in the organization: the view of managers in education system and school managers to the issue of spirituality at work can help improvement of such behaviors and consequently improve the performance of schools. Therefor managers must take workplace spirituality very seriously and try to enhance the spirituality of the work environment. By taking measures such as job rotation, job enrichment and employees' empowerment and also by making the job more enjoyable, managers can improve employees' perception of workplace spirituality. Surveying employees about the values of education and attention to employees' moral health and living conditions can lead to acceptance of goals and values 
of education by the teachers. It is suggested that the mentioned managers pay close attention to teachers' spiritual needs and try to create a dynamic and stimulating environment. Through taking such measures we can hope that teachers indulge more in their work and demonstrate more signs of organizational citizenship behaviors.

\section{References:}

1. Ahmadi A, Khoddami A (2011). A model for study of general citizenship behaviors, spirituality and organizational citizenship behavior in Iran's governmental sections (a study of Iran insurance company). General management studies, 4, No.14, pp107-28

2. Ahmadi s, name y and barvarz r(2014). The Relationship Between Spirituality In The Workplace And Organizational Citizenship Behavior. Procedia - Social and Behavioral Sciences $114,262-264$.

3. Ashmos, D p and Dennis D(2000).Spirituality at Work: A conceptualization \& measure,Journal ofManagement, Vol. 9, No.2, pp..145-134.

4. Beikzadeh, Yazdani, Hamdollahi (2011). Workplace spirituality and its effect on components of organizational citizenship behavior, Educational management studies scientific periodical, 3, No.1

5. Cavanagh, G(1999). Spirituality for Managers: Context and Critique, Journal of Organization Change Management, Vol 12 . No 3.pp 53-163.

6. Castro, C.B\& Armario,E.M(2004).the influence of employee organizationl citizenship behavior on customer loyalty.international journal of service industry management , 115.20-30.

7. Doaee H And Azizi M (2012). The Impact of Spirituality on Organizational Citizenship Behavior with an Emphasis on the Mediating role of Organizational Commitment,Iranian Journal of Development Management, No. 8, pp. 29-51.

8. DiPaola, M. F. \& da Costa Neves, P.M.M (2009). Organizational citizenship behaviors in American and Portuguese public schools, Journal of Educational Administration, Vol. 47 No. 4, pp. 490-507.

9. Erturk(2006), increasing organizational citizenship behaviors of Turkish academicians, Journal of Managerial psychology.

10. Kutcher, E. J.; Bragger, J. D.; RodriguezSrednicki, O., \& Masco, J. L (2010). The role of religiosity in stress, job attitudes, and organizational citizenship behavior. Journal of Business Ethics, 95, 319-337.
11. Nikpour, A., Manzari Tavakoli, AR., and Hosseininejad, MR( 2012). "Examining the relationship between workplace spirituality and organizational citizenship behavior in employees of Foundation of Martyrs and Veterans Affairs in city of Kerman, Beyond Management, no 16, pp.172-155

12. Sharifzade $F(2009)$. The relationship between employee empowerment and human resource personnel productivity of staffs of Lorestan Police. J Manage Stud Police Officer. 4(1):pp7-19.

13. Shahabinia S And Aghabasiri Sarabi S (2013). The relationship between Organizational Spirituality and Organizational Citizenship Behavior (A Case Study: Social Security Employees in Tuyserkan, [14] Hamedan, Iran, Proceedings of the Third International Conference on Behavioral Sciences, Kish Island, Iran, Kamal-al-Molk Press.

14. Sprung, Justin M., Sliter, Michael T., Jex, Steve M. (2012) Spirituality as a moderator of the relationship between workplace aggression and employee outcomes. Personality and Individual Differences, Volume 53, Issue 7, Pages 930934.

15. Taia, Cheng.Ling.,Chang, TChe-Ming., Hong, TJhao-Yu., Chend, TLi-Chun.(2012). Alternative models for the relationship among leadership, organizational citizenship behavior, and performance. a study of new product development teams in Taiwan. Procedia Social and Behavioral Sciences , $511-517$.

16. Taleghani Gh,Mohammad $\mathrm{M}$ and Rostami $\mathrm{H}$ (2012). Effectiveness of Organizational Spirituality in Improving Organizational Citizenship Behavior (A Case Study: City of Zahedan, Iran). Iranian Journal of Organizational Culture Management,Volume XI, No. II, pp. 163-188.

17. Tepper, B. J. (2003). Organizational citizenship behavior and the spiritual employee. In R. A. Giacalone \& C. L. Jurkiewicz (Eds.), Handbook of workplace spirituality and organizational performance (pp. 181-190). Armonk, NY: M. E. Sharpe. 